

\section{Sumário}

I. CRônicas

A Favor de uma Corte Latino-Americana de Justiça ..................................................... 3 Nitish Monebhurrun

Sobre A SOluÇão JUdicial de CONTROvérsias Na AMÉRICA LATINA 7 Lucas Carlos Lima

A Favor de uma Corte Latino-Americana de Justiça - Uma Reação sobre a Legalidade e A Legitimidade De Seu Desenho Institucional............................................................15

Arthur Roberto Capella Giannattasio

O Estudo do Direito Internacional sob uma Nova Perspectiva: Nossa Experiência na Philip C. Jessup International Moot Court Competition............................................20 Ana Vitória Muniz Bokos, Igor Medeiros Maia, Jefferson Seidy Sonobe Hable, Gabriel de Oliveira Borba, Gilda Nogueira Paes Cambraia e Nayara Lima Rocha Da Cruz

Revisión de laudos de arbitrajes de inversión 2019: I Encuentro Anual (Santiago de

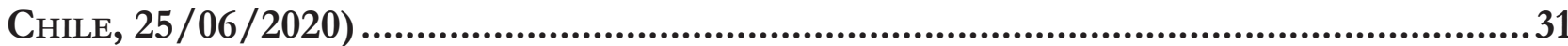
Andrés Delgado Casteleiro e Ivette Esis

II. Dossiê: Populismo e Direito Internacional / Populism and Internatio-

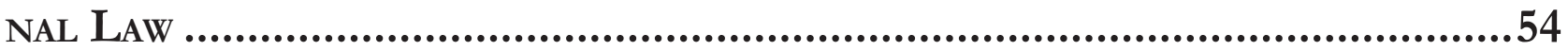

Editorial: Populism and International Law: Global South Perspectives .56 Lucas Lixinski e Fabio Morosini

Editorial: Populismo e Direito Internacional: Perspectivas do Sul Global .61 Lucas Lixinski e Fabio Morosini 
Between Science and populism: the Brazilian Response to COVID-19 from the Perspective of the legal determinants of Global Health

Deisy de Freitas Lima Ventura e Jameson Martins

Populism, ENVIronmental LAW, AND THE POST-PANDEMiC ORDER Alessandra Lehmen

Populism and the Evangelical church in Latin America: how anti-LGBTI forces TRIED TO STOP THE COLOMBIAN PEACE AGREEMENT Julia Assmann de Freitas Macedo e Fabrízio Conte Jacobucci

“Deus EM Davos": o Direito INTERnACIONAL ENTRE REACIONÁRIOS E NEOLIBERAIS NO GOVERNO BOLSONARO 121

Lucas Tasquetto e João Roriz

CHINESE POPULISM IN THE 1920s, EXTRATERRITORIALITY AND INTERNATIONAL LAW 139 Wanshu Cong

CONCEPTUALIZING UNILATERALISM, FRAGMENTATIONISM AND STATISM IN A POPULISM CONTEXT: A RISE OF POPULIST INTERNATIONAL LAW? 162 Wei Shen e Carrie Shu Shang

AUTONOMÍA ADMINISTRATIVA SIN AUTONOMÍA POLÍTICA: LA APLICACIÓN DEL MODELO "UN PAÍS dos SISTEMAs" eN HoNg Kong 186 Juan Enrique Serrano Moreno

III. Artigos sobre outros temas...................................................... 197

Um TWAiler entre nós? As contribuições de Celso Duvivier de Albuquerque Mello PARA O DIREITO INTERNACIONAL (CRÍTICO) NO BRASIL .................................................... 199

Fabio Morosini e Matheus Leichtweis

DEMOCRACIES IN DANGER: ARE JUDICIAL DIALOGUES MEANS TO REFRAIN SETBACKS IN LATIN America?.

Melina Girardi Fachin e Bruna Nowak 


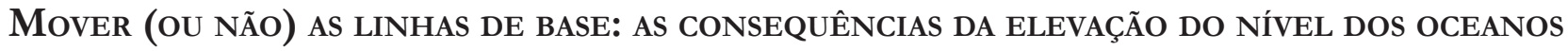
SOBRE AS ZONAS MARÍTIMAS DOS PEQUENOS ESTADOS INSULARES EM DESENVOLVIMENTO E AS ALTERNATIVAS JURÍDICAS PARA REDUZIR SEUS IMPACTOS

Alexandre Pereira da Silva

A mineração em águas profundas no Pacífico 263 Pierre-Jean Bordahandy

Dual Nationality and International Law in times of Globalization. Challenges and Opportunities for Consular Assistance and Diplomatic Protection in RECENT CASES. 288

Walter Arevalo-Ramirez e Robert Joseph Blaise Maclean

Expulsion of aliens: the application of International Law by Chilean Superior Courts 309

Regina Ingrid Díaz Tolosa

O TIPO PENAL BRASILEIRO DE PROMOÇÃo DE MIGRAÇÃO ILEGAL E O PRINCÍPIO DA NÃO CRIMINALIZAÇÃo DA MOBILIDADE HUMANA

Regina Cândido Lima e Silva Santos e Deilton Ribeiro Brasil

INDICADORES TRANSNACIONAIS DE CORRUPÇÃO AMBIENTAL: A OPACIDADE NA TRANSPARÊNCIA INTERNACIONAL

Márcio Ricardo Staffen

SubTRAÇÃo INTERNACIONAL DE CRIANÇAS: ANÁLISE DAS EXCEÇÕES AO RETORNO IMEDIATO DO MENOR À RESIDÊNCIA HABITUAL E CRÍTICA AO ENQUADRAMENTO DA VIOLÊNCIA DOMÉSTICA COMO FLEXIBILIDADE PERMISSIVA

Vivian Daniele Rocha Gabriel

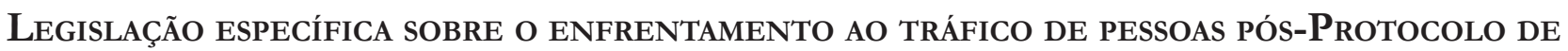
Palermo (2000): análise do Estado de Moçambique 383

Mercia Cardoso de Souza, Guirino Dinis José Nhatave e Francisco Horácio da Silva Frota 
IV. Artigos traduzidos

DIREITO INTERNACIONAL DO RECONHECIMENTO

Emmanuelle Tourme-Jouannet e Tradutor: Ademar Pozzatti Junior

V. RESENHAS

Fabio Costa Morosini, Gabriel Lee Mac Fadden Santos, Valentina Fonseca da Luz e Vinicius Tejadas Maia 


\title{
Populism and the Evangelical church in Latin America: how anti-LGBTI forces tried to stop the Colombian peace agreement*
}

\author{
Populismo e Igreja Evangélica na América \\ Latina: como as forças anti-LGBTI tentaram \\ impedir o acordo de paz colombiano
}

Julia Assmann de Freitas Macedo**
Fabrízio Conte Jacobucci***

\begin{abstract}
The present paper explores the relationship between right-wing populism and the neo-Pentecostal Evangelical churches in Latin America, focusing on the anti-LGBT discourse emanating from this relationship. It argues that right-wing populists have been antagonizing the "people" against an imaginary LGBTI foe and using religious jargon and support to mobilize the masses against gender identity and sexual orientation achievements in the region. This argument is illustrated by a case study on one of the most emblematic moments of anti-LGBTI rhetoric in the last decade: the 2016 peace agreement referendum in Colombia. After more than fifty years of war between the FARC-EP and the government, a religious-populist movement claimed the Colombian peace agreement was tainted by "gender ideology", which would threaten Colombian traditions and institutions. The 2016 referendum became a platform for advancing and repudiating LGBTI rights, and the subsequent rejection of the Colombian peace agreement is a case in point of the sharp opposition and "us vs them" narrative of right-populists and the neo-Pentecostal church against the LGBTI agenda.
\end{abstract}

Keywords: Latin America. Populism. Neo-Pentecostal churches. LGBTI. Peace agreement. Colombia.

* Recebido em 15/04/2020

Aprovado em 27/08/2020

* Mestre em Direito Internacional Humanitário e Direitos Humanos pela Geneva Academy of International Humanitarian Law and Human Rights. Bacharel em Direito pela Universidade Federal do Rio Grande do Sul. Email: juliaafmacedo@gmail.com

** Mestrando em Direito das Relações Econômicas Internacionais na Pontifícia Universidade Católica de São Paulo (PUC-SP). Especialista em Direito Internacional pela Pontifícia Universidade Católica de São Paulo (PUC-SP). Bacharel em Direito pelas Faculdades Integradas de Ourinhos. Professor na Pós-Graduação em Direito e Relações Internacionais da Escola Paulista de Direito. Email: fcjacobucci@gmail.com

\section{Resumo}

O presente artigo explora a relação entre o populismo de direita e as igrejas evangélicas neopentecostais na América Latina, enfocando o discurso antiLGBT que emana dessa relação. Argumenta-se que populistas de direita têm antagonizado o "povo" contra um inimigo LGBTI imaginário e usando jargão religioso e apoio para mobilizar as massas contra as conquistas de identidade de gênero e da orientação sexual na região. Esse argumento é ilustrado por um estudo de caso sobre um dos momentos mais emblemáticos da retórica anti-LGBTI na última década: o referendo do acordo de paz de 2016 na Colômbia. Depois de mais de cinquenta anos de guerra entre as FARC-EP e o governo, um movimento religioso-populista afirmou que 
o acordo de paz colombiano estava contaminado pela "ideologia de gênero", o que ameaçaria as tradições e as instituições colombianas. O referendo de 2016 tornouse uma plataforma para avançar e repudiar os direitos LGBTI, e a subsequente rejeição do acordo de paz colombiano é um caso em destaque na forte oposição e na narrativa "nós contra eles" de populistas de direita e da igreja neopentecostal contra o Agenda LGBTI.

Palavras-chave: América Latina. Populismo. Igrejas neopentecostais. LGBTI. Acordo de Paz. Colômbia

\section{Introduction}

Sandwich. That is the word Juan Manuel Santos, Nobel Peace Prize laureate and Colombia's former president, utilized to describe Latin America's current political situation. "Latin America is like a sandwich, between left- and right-wing populism", he affirmed during an interview with a Colombian TV program ${ }^{1}$. Indeed, if considered against an historical background, the statement could well be sound. Populism is a thin-centered ideology, which grips itself into other more complex and stable host ideologies, such as nationalism, liberalism, and socialism². Latin America has flirted with those, and since the 1930s the region swung between left- and right-wing populists. It pushed through Peron, Vargas, Velasco, Ibarram, Fujimori, Chaves, Collor de Mello, Ortega, and Correa, among many others. Although not free of controversy and with representatives holding uneven levels of populist appeal, Manuel Santos is right to assert that the region has seen the rise and fall of different versions of populism.

However, Santos' declaration is not befitting to the events of recent years. By the mid-2010s, a conservative wave struck the world and its ripples were felt across Latin America - the right-wing nationalism spearheaded by Trump, Orbán and Haider has had a comparable variant in the tropics. The phenomena in the Global North and Latin America have much in common: the

CADENA SER. Juan Manuel Santos: América Latina está como un sándwich, entre el populismo de izquierdas y de derechas. mar. 2019. Available at: https://cadenaser.com/programa/2019/03/27/ hoy_por_hoy/1553671611_425302.html.

2 MUDDE, Cas. The populist zeitgeist. Government and Opposition, v. 39, n. 4, p. 541-563, 2004. MUDDE, Cas; KALTWASSER, Cristóbal Rovira. Populism: a very short introduction. Oxford: Oxford University Press, 2017. reinforcement or open legitimization of racism, homophobia, intolerance and nationalism, as well as a dystopian normalization of ignorance and the naturalization of violence ${ }^{3}$. Despite the overarching polarization of the electorate, both North and South have witnessed a turn to the right ${ }^{4}$. However, recent right-wing populist movements in Latin America are backed by a unique factor that cannot be found in other regions of the world: the support and strong alliance with the neo-Pentecostal Evangelical church ${ }^{5}$.

In Latin America, populists are usually charismatic personalities who maintain a direct connection to the people. However, its right-wing and conservative representatives are seen as part of the upper strata, faring best among their equals, and tend to struggle reaching the masses ${ }^{6}$. To shift this trend, Evangelical rhetoric has been (falsely) employed as a bridge between conservative right-wing populists and the people, in order to spread their agenda to all social and economic groups. Evangelical churches have turned into populist enablers. In this sense, the region is not stuck between left- and right-wing populism, but rather (as Juan Manuel Santos himself would experience in 2016) between neo-Pentecostal Evangelical churches and the latter. The relationship between them is far more complex than the terms proposed by Santos: right-wing populists and neo-Pentecostal leaders coordinate forces, reinforce each other's power and advance a shared agenda.

In parallel, the LGBTI agenda has gained some momentum in the last decade, and the struggle for their rights in Latin American countries has made unprecedented, though still modest, inroads ${ }^{7}$. As a result, the

GIROUX, Henry A. Crescimento do populismo de direita. Le Monde Diplomatique Brasil, ed. 151, jan. 2020. Available at: https:// diplomatique.org.br/crescimento-do-populismo-de-direita/.

4 GANDESHA, Samir. Understanding right and left populism. In: MORELOCK, Jeremiah (org.). Critical theory and authoritarian populism. London: University of Westminster Press, 2018. p. 49-70.

5 Although the support and alliance between right-wing populists and Evangelicals can be found in others regions of the world, the dimension of this phenomenon in Latin America is unprecedent.

6 Conservative parties tend to draw their core constituencies from the upper strata of society, however some noteworthy exceptions such as Collor de Mello in Brazil should be highlighted. MAINWARING, Scott; MENEGUELLO, Rachel; POWER, Timothy J. Conservative parties, democracy, and economic reform in contemporary Brazil. In: MIDDLEBROOK, Kevin J. Conservative parties, the right, and democracy in Latin America. Baltimore: The Johns Hopkins University Press, 2000. p. 164-222.

CORRALES, Javier; PECHENY, Mario. Introduction: the comparative politics of sexuality in Latin America. In: CORRALES, Javi- 
populist-evangelical backlash against sexuality and identity debates has been razor-sharp, trying to silence critics, consolidate power, and turning the LGBTI agenda into a battleground. This radical movement, which does not stand for all Evangelicals or populists, fosters campaigns against minorities and has found in the LGBTI community an enemy against whom to fight ${ }^{8}$. As LGBTI rights were brought to the center of the political debate, right-wing populist and Evangelical fronts started to press in the same direction, announcing a crusade against the so-called "gender ideology".

The present paper will argue that although it is undeniable that left-wing populism still plays an import role in the region, the current "sandwich" in Latin America rather involves right-wing populism and the neo-Pentecostal Evangelical church. This paper tackles the anti-LGBTI discourse stemming from it. Although there is no necessary mismatch between LGBTI rights and Evangelical ethics, it will argue that right-wing populists have been using religious jargon and mobilizing the masses against LGBTI achievements. This argument will be illustrated by a case study on one of the most emblematic moments of anti-LGBTI rhetoric in the region: the 2016 referendum in Colombia. After more than fifty years of war between the FARC-EP and the government, a religious-populist movement claimed the peace agreement was tainted by "gender ideology", which threatened Colombian traditions and institutions. Inspired by an anti-LGBTI discourse and rooted in an "us vs them" paranoia, the rejection of the Colombian Peace Agreement is a case in point of the power of anti-LGBTI discourse emanating from both right-wing populism and the neo-Pentecostal Evangelical churches.

\section{Populism and the Evangelical church in Latin America}

\subsection{The populist quest for an enemy}

er; PECHENY, Mario (org.). The politics of dexuality in Latin America. Pittsburgh: University of Pittsburgh Press, 2010. p. 1-30.

8 It is importante to highlight that some Protestant congregations promote gender equality and rights for the LGBTI community. For instance, the Colombian movement Redconciliarte, encourages LGBTI Christians to express their faith publicly and mobilize in defense of their rights.
There is a lot of debate behind the meaning and scope of the different forms of populism. However, resorting to Cas Mudde's definition, all forms of populism include an appeal to "the people" and a denunciation of "the elite". What makes populism so powerful and the bearer of different facets is that both the people and the elite are flexible and abstract constructions, differentiated only by a key moral factor: "the people" is pure, and "the elite" is corrupt ${ }^{10}$.

The concept of "people" is broad enough to encompass different constituencies and articulate their demands, to generate a shared identity between different groups and facilitate their support for a common cause. According to the populist rhetoric, the "people" is objectively or subjectively excluded from power. This exclusion can occur for a variety of reasons, including cultural, national, economic, ethnic and social characteristics. The idea is both inclusive and divisive, as it simultaneously attempts to unite an angry and silent majority, while mobilizing this majority against a defined enemy ${ }^{11}$.

Populists encourage antagonist and manicheistic narratives, fostering the idea of "us vs them". They also introduce the sense of lack of representation by existing political parties and spread a feeling of irreparable disorder. The objective is to maximize the need for the people to turn against the current political arrangement. By inducing people to seek unconventional actors to have their demands guaranteed - since institutions, the press and the Congress no longer represent trusted platforms - populists consolidate their position as the anti-establishment ${ }^{12}$. The rupture with the existent establishment is a consequence of the loss of reliability that the political system can find a cure to its disease (social disorder) within itself. People are consumed by the belief that the only path is deconstructing the current political system in order to

\footnotetext{
MUDDE, Cas. The populist zeitgeist. Government and Opposition, v. 39, n. 4, p. 541-563, 2004.; MUDDE, Cas; KALTWASSER, Cristóbal Rovira. Populism: a very short introduction. Oxford: Oxford University Press, 2017.

10 MUDDE, Cas. The populist zeitgeist. Government and Opposition, v. 39, n. 4, p. 541-563, 2004.; MUDDE, Cas; KALTWASSER, Cristóbal Rovira. Populism: a very short introduction. Oxford: Oxford University Press, 2017.

11 MUDDE, Cas. The populist zeitgeist. Government and Opposition, v. 39, n. 4, p. 541-563, 2004.; MUDDE, Cas; KALTWASSER, Cristóbal Rovira. Populism: a very short introduction. Oxford: Oxford University Press, 2017.

12 BAVA, Silvio Caccia; ROMANO, Jorge. Vamos falar de populismo. Le Monde Diplomatique Brasil, ed. 120, jul. 2017. Available at: https://diplomatique.org.br/vamos-falar-de-populismo-2/.
} 
build a brand-new project. However, nothing new comes from this endeavor ${ }^{13}$. Through populists' emphatic speech, they meticulously sew a scenario in which the people think they can only rely on the leader's maintenance in power to assure their own rights ${ }^{14}$.

In this sense, populism is fundamentally an anti-establishment phenomenon, and such notion can be objective or subjective. The "elite" is what is seen as the establishment, the ones with the real power, the privileged ones. What is interesting is that the populist arguments affirm that they, the democratically elected leaders, are not the ones who hold the real power, but some shadowy forces that continue to hold on to illegitimate powers to undermine the voice of the pure people $^{15}$.

Although not all populist movements look the same ${ }^{16}$, they all share the same objective: holding on to power ${ }^{17}$. By giving voice to the people, this phenomenon institutes a sense of belonging, in which both people and governors are on the same empowered side of the coin.

In Latin America, populism is particularly appealing because of the region's high levels of socioeconomic inequality. During the $20^{\text {th }}$ century, populism movements seized the power vacuum caused upon the fall of traditional oligarchic systems ${ }^{18}$. These movements are traditionally divided into three waves. First, the national-populism in the 1930's, in which boosted by the new urban masses Vargas in Brazil, Perón in Argentina, Velasco in Ecuador, Cárdenas in Mexico and Haya de la Torre in Peru, promoted the universal vote, the inclu-

\footnotetext{
13 BAVA, Silvio Caccia; ROMANO, Jorge. Vamos falar de populismo. Le Monde Diplomatique Brasil, ed. 120, jul. 2017. Available at: https://diplomatique.org.br/vamos-falar-de-populismo-2/.

14 HERNANDEZ, Alejandro Espí. La dimensión emocional de los movimientos políticos populistas de S.XXI en América Latina y Europa. Miguel Hernández. Communication Journal, v. 10, n. 1, p. 101121. Universidad Miguel Hernández, UMH (Elche-Alicante). DOI: http://dx.doi.org/10.21134/mhcj.v10i0.277.

15 MUDDE, Cas. The populist zeitgeist. Government and Opposition, v. 39, n. 4, p. 541-563, 2004. MUDDE, Cas; KALTWASSER, Cristóbal Rovira. Populism: a very short introduction. Oxford: Oxford University Press, 2017.

16 MULLER, Jan Werner. Populism and the people. London Review of Books. may 2019. Available at: https://www.lrb.co.uk/the-paper/ v41/n10/jan-werner-mueller/populism-and-the-people.

17 BAVA, Silvio Caccia; ROMANO, Jorge. Vamos falar de populismo. Le Monde Diplomatique Brasil, ed. 120, jul. 2017. Available at: https://diplomatique.org.br/vamos-falar-de-populismo-2/.

18 PRADO, Maria Ligia; PELLEGRINO, Gabriela. História da América Latina. São Paulo: Contexto, 2014.
}

sion of workers and a social protection system. Second, the right-wing neo-populism in early 1990's, in which Fujimori in Peru, Menen in Argentina and Collor de Melo in Brazil intended to institute neo-liberal economic measures aligned with Washington's politics by privatizing and reducing the State's size - leaving a commercial balance that required a deep political, social and economic reconstruction. Third, the left-wing populism in the late 1990's and 2000's, in which Chavez in Venezuela, Lula in Brazil, Kirchner in Argentina, Correa in Ecuador and Morales in Bolivia advanced an anti-neo-liberal economic position, strengthening the role of the State by nationalizing natural resources ${ }^{19}$.

In addition, a fourth wave of populism has been surrounding Latin America since 2010's: the ultra-right-wing conservative populism ${ }^{20}$. Bolsonaro in Brazil, Morales and Giammattei in Guatemala, Macri in Argentina, Piñera in Chile, and Hernández in Honduras are examples of a turn to the right ${ }^{21}$. Fourth-wave populists have taken advantage of people's social discontent and provided a conservative, nationalist and fundamentalist agenda.

The fourth wave of populism established a strong connection with neo-Pentecostal Evangelical churches. Right-wing populists have penetrated the neo-Pentecostal masses due to the conservative values shared by both $^{22}$. The interplay between these actors has reinforced the perpetuation of right-wing governments in the region. Additionally, in the last decade a political crisis grew, as the economical upper strata refused to accept extending social benefits to new subjects and clamoured for a return to institutional representation of the elite interests - perfect timing for a conservative project ${ }^{23}$.

19 GRATIUS, Susanne. La "tercera ola populista” de América Latina. Working paper to the Fundación para las Relaciones Internacionales y el Diálogo Exterior (FRIDE). oct. 2007. Available at: https:// s3.amazonaws.com/academia.edu.documents/42469813/La_tercera_ola_populista_de_Amrica_Latin20160209-25129-13dj5fo.pdf. 20 LAMBERT, Renaud. O impasse da direita da América Latina. Le Monde Diplomatique Brasil, ed. 152, fev. 2020. Available at: https:// diplomatique.org.br/o-impasse-da-direita-na-america-latina/.

21 BELLOLIO, Cristóbal. La cuarta ola de populismo latinoamericano. Revista Capital, sep. 2018. Available at: https://www.capital.cl/ la-cuarta-ola-de-populismo-latinoamericano/.

22 CORRALES, Javier. A perfect marriage: evangelicals and conservatives in Latin America. The New York Times, jan. 2018. Available at: https://www.nytimes.com/2018/01/17/opinion/evangelicalspolitics-latin-america.html.

23 BAVA, Silvio Caccia; ROMANO, Jorge. Vamos falar de populismo. Le Monde Diplomatique Brasil, ed. 120, jul. 2017. Available at: https://diplomatique.org.br/vamos-falar-de-populismo-2/. 
In Costa Rica, same-sex marriage debates directly influenced the 2018 presidential ballot. In response to a Costa Rican government consultation, the Interamerican Court of Human Rights has obliged the State to guarantee equal rights to same-sex marriage ${ }^{24}$. This decision caused a commotion by Evangelical groups, and led Fabricio Alvarado, a gospel singer and TV presenter, to jump from $3 \%$ to $25 \%$ of voting intention in the presidential campaign. He would ultimately lose the ballot to Carlos Quesada, but he managed to gather all conservative fronts involved with the same agenda ${ }^{25}$. In Paraguay, Mario Abdo Benítez was elected with support of conservative Christian movements by revisiting Alfredo Stroessner's (20 ${ }^{\text {th }}$ century Paraguayan dictator) tough speech on prohibition of same-sex marriage and abortion ${ }^{26}$. In Guatemala, Alejandro Giammattei, a right-wing former prison chief commandant, gained victory through the Evangelical masses with his conservative anti-LGBTI stance in $2019^{27}$. The same happened in Chile, where Sebastian Piñera, a right-wing conservative billionaire, was elected with a very similar agenda in $2018^{28}$, and in Honduras, where Juan Orlando Hernandez was reelected after a controversial ballot, with a right-wing conservative agend $\mathrm{a}^{29}$.

\subsection{The neo-Pentecostal Evangelical Church enters the scene}

The relationship between politics and religion is not an exclusive aspect of neo-Pentecostal churches

24 MARIANO, Ricardo; GERARDI, Dirceu André. Eleições presidenciais na América Latina em 2018 e ativismo político de evangélicos conservadores. Revista da Universidade de São Paulo, n. 120, p. 61-76, 2019.

25 PRETEL, Enrique Andres. Christian singer faces leftist author in Costa Rica presidential runoff. Reuters, feb. 4, 2018. Available at: https://www.reuters.com/article/us-costarica-election/christiansinger-faces-leftist-author-in-costa-rica-presidential-runoff-idUSKBN1FP0QE.

26 MARIANO, Ricardo; GERARDI, Dirceu André. Eleições presidenciais na América Latina em 2018 e ativismo político de evangélicos conservadores. Revista da Universidade de São Paulo, n. 120, p. 61-76, 2019.

27 BBC NEWS. Conservative Alejandro Giammattei wins Guatemalan presidency. BBC News, aug. 2019. Available at: https://www. bbc.com/news/world-latin-america-49278325.

28 BBC NEWS. Chile election: conservative Piñera elected president. BBC News, dec. 2019. Available at: https://www.bbc.com/ news/world-latin-america-42388019.

29 THE GUARDIAN. Honduran president makes contentious bid for second term. The Guardian, nov. 2017. Available at: https:// www.theguardian.com/world/2017/nov/24/honduras-presidenthernandez-contentious-bid-second-term-elections. and populism. Religion has always been rooted in the social, political and economic development of Latin America $^{30}$. It is intrinsically related to the "discovery" and exploitation of the region itself, due to the deep connection of both Spain and Portugal to the Roman Catholic Church ${ }^{31}$. The Church has been involved in the region's political matters since the Tordesillas Treaty, passing through the independence of the new-born States and the establishment of a democratic concert in the region ${ }^{32}$.

In 1970, Roman Catholics represented $92 \%$ of Latin America's population, a consequence of affiliation between the State and the Church through the centuries ${ }^{33}$. Due to the urbanization of Latin America's society, the increasing plurality of religions, and uneven globalization, the region's cultural identity has been directly impacted. As a result, Latin America experienced a fragmentation of its religious bonds with Catholicism ${ }^{34}$. By breaking up with the steady identity of Catholic Latin America, the region experienced a new scenario in which Non-Catholic Christian religions started occupying a growing role within society: the expansion of the Evangelical church is its most prominent example ${ }^{35}$. In 2014, the percentage of Catholics had dropped to $69 \%$, while the percentage of Evangelical faithful had jumped from $4 \%$ to $19 \%{ }^{36}$.

The label 'Evangelical' in Latin America is an um-

30 PENYAK, Lee M.; PETRY, Walt J. Religion in Latin America: a documentary history. New York: Orbis Books, 2006.

31 Christianity spread through the Iberian Peninsula during second and third centuries. In the following centuries, Roman Catholic Church would play an important role in the constitution of both Portugal and Spain as independent Catholic declared States. Further on, the Church would still be a decisive player throughout the colonization of Latin America. PAYNE, Stanley G. A history of Spain and Portugal. The Library of Iberian Resources Online. Available at: https://libro.uca.edu/payne1/spainport1.htm.

32 PAYNE, Stanley G. A history of Spain and Portugal. The Library of Iberian Resources Online. Available at: https://libro.uca.edu/ payne1/spainport1.htm.

33 PEW RESEARCH CENTER. Religion in Latin America: widespread change in a historically catholic region. Pew Research Center, nov. 13, 2014.

34 SILVA, Hélerson. Os novos atores "evangélicos" e a conquista do espaço público na América Latina. Reflexão, v. 43, n. 2 , p. 243-263, 2018. Available at: http://dx.doi.org/10.24220/2447-6 803v43n2a4377.

35 SEMÁN, Pablo. ¿Quiénes son? ¿Por qué crecen? ¿En qué creen? Pentecostalismo y política en América Latina. Revista Brasileira de Ciências Sociais, v. 34, n. 99, p. 26-45, 2019.

36 PEW RESEARCH CENTER. Religion in Latin America: widespread change in a historically catholic region. Pew Research Center, nov. 13, 2014. 
brella term used to describe a strand of Protestantism, which often encompasses most of the 'transplanted' and independent churches in the region ${ }^{37}$. Evangelical churches derive from Protestantism and are assembled in a Christian movement that strictly follows the Bible - and not the Pope, as with Catholics. The very word "evangelicalism" comes from evangelii (Gospel, in Latin), whereas the Roman Catholic and Apostolic Church derives its name from St. Peter, one of Jesus' apostles and first leader of the Church $^{38}$. For centuries, Protestantism has defended values of equality, liberty and individual autonomy of thought, opinion and expression ${ }^{39}$.

According to Allan Lichtman, since the end of World War I, North American white Protestant groups have led conservative movements based on the anti-pluralist Christian tradition, focused on the family, defense of male authority, and radical opposition to abortion and homosexuality. These groups have strengthened right-wing politics with passionate appeal to do whatever is necessary to control private morality and public life - even if it means to instrumentalize government and the State's apparatus ${ }^{40}$.

Since the 1970's, new Christian right-wings have gathered in a neo-Pentecostalism movement, aiming to show reaction to cultural, political and social changes worldwide. In order to accomplish this, the movement has employed political artifices to reintroduce Christian conservative values into the public arena ${ }^{41}$. During the last decades, this new segment within Evangelical creed has expanded. Flourishing through both autonomous churches and being adopted, in whole or in part, by existing organizations ${ }^{42}$. Neo-Pentecostalism is based

\footnotetext{
37 GUADALUPE, José Luis Pérez. Evangelicals and political power in Latin America. Lima: Konrad-Adenauer-Stiftung \& Institute of Social Christian Studies of Peru (IESC), 2019.

38 SEMÁN, Pablo. ¿Quiénes son? ¿Por qué crecen? ¿En qué creen? Pentecostalismo y política en América Latina. Revista Brasileira de Ciências Sociais, v. 34, n. 99, p. 26-45, 2019.

39 MARIANO, Ricardo; GERARDI, Dirceu André. Eleições presidenciais na América Latina em 2018 e ativismo político de evangélicos conservadores. Revista da Universidade de São Paulo, v. 120, p. 61-76, 2019.

40 MARIANO, Ricardo; GERARDI, Dirceu André. Eleições presidenciais na América Latina em 2018 e ativismo político de evangélicos conservadores. Revista da Universidade de São Paulo, v. 120, p. 61-76, 2019.

41 GUADALUPE, José Luis Pérez. Evangelicals and political power in Latin America. Lima: Konrad-Adenauer-Stiftung \& Institute of Social Christian Studies of Peru (IESC), 2019.

${ }^{42}$ URUEÑA, Rene. Reclaiming the keys to the kingdom (of the World): evangelicals and human rights in Latin America. Netherlands
}

on the so-called "prosperity theology" - a theory sustaining that if God was able to cure the soul, then there would be no reason to think He could not give economic prosperity as well. The faithful counterpart would be provided by the tithe ${ }^{43}$. It is the manifestation of the so-called Protestant liberalism, as it encourages the personal economic progress of the faithful. As a segment of Protestantism, neo-Pentecostalism has played a modernizing role in the region's archaic dogmas, whilst introducing a fundamentalist perspective ${ }^{44}$.

Because of its deeply personal, charismatic, and transformative features, the number of faithful of this creed has sharply expanded across Latin America. Based on flexible but arranged organizations, and the ability to bind its message to local spiritualities ${ }^{45}$, neo-Pentecostal churches easily reach several segments of the population, and are integrated not just into big centers, but also into poor, rural, and marginalized neighborhoo$\mathrm{ds}^{46}$. Its activities run across class, race, and region ${ }^{47}$. These churches have been thriving on providing better answers to Latin Americans' needs, who have been struck by swift social changes, globalization, and deep inequality ${ }^{48}$. Conversely to the Catholic church which has a centralized authority, neo-Pentecostal churches are conducted by their own local leaders and, thus, are able to ground its activities within multiple centers with very little hierarchy. Its expansion in Latin America is financially and organizationally decentralized, with small-scale leadership working close to the faithful ${ }^{49}$. Unlike

Yearbook of International Law: Populism and International Law, p. 175-208, 2018.

43 SEMÁN, Pablo. ¿Quiénes son? ¿Por qué crecen? ¿En qué creen? Pentecostalismo y política en América Latina. Revista Brasileira de Ciências Sociais, v. 34, n. 99, p. 26-45, 2019.

${ }^{44}$ MARIANO, Ricardo; GERARDI, Dirceu André. Eleições presidenciais na América Latina em 2018 e ativismo político de evangélicos conservadores. Revista da Universidade de São Paulo, v. 120, p. 61-76, 2019.

45 SEMÁN, Pablo. ¿Quiénes son? ¿Por qué crecen? ¿En qué creen? Pentecostalismo y política en América Latina. Revista Brasileira de Ciências Sociais, v. 34, n. 99, p. 26-45, 2019.

46 BOAS, Taylor. Serving God and man: evangelical christianity and electoral politics in Latin America. Annual meeting of the American Political Science Association, Chicago, IL, aug. 29-sep. 1, 2013.

47 SMILDE, David. Los evangélicos y la polarización. Revista Venezolana de Economía y Ciencias Sociales, v. 10, n. 2, p. 163-79, 2010.

48 SABOGAL, Julián. Evangélicos se consolidan cada vez más como una fuerza política en Suramérica. RCN Radio, 2018. Available at: https://www.rcnradio.com/internacional/evangelicos-seconsolidan-cada-vez-mas-como-una-fuerza-politica-en-suramerica. 49 SILVA, Hélerson. Os novos atores "evangélicos" e a conquista do espaço público na América Latina. Reflexão, v. 43, n. 2, p. 243263, 2018. 
other religious cults, the neo-Pentecostal churches are in tune with the people, and engage them with creative and stimulating activities (family parties, raffles, and dances) to connect people among themselves and with the religion ${ }^{50}$. Thus, the religion is "close to home", and it creates a sense of belonging and community.

This new segment of Evangelical religion has proved itself highly successful in Latin America and, since the outset, the neo-Pentecostal movement has flirted with conservatism. Within Latin American society, the conservative tide was boosted by a feeling of disappointment towards more socially progressive initiatives and was sped up by social media. Neo-Pentecostal leaders caught this ride. They also turned the religion into a networking event, building ties with other conservative social organizations ${ }^{51}$.

In some Evangelical groups, it is possible to identify a growing "populist style". According to URUENA, the neo-Pentecostal movement "shares the forms (and even the esthetics) of populist movements, characterized by the ambition of social and political transformation, economic benefits for the most dispossessed, and a strong base of social support for favored policies" 52 . Right-wing populists played with these characteristics, using the Evangelical sense of belonging, and converting it into an "us vs them" dynamic. They have resorted to Evangelical jargon to address the people and make themselves "close to home" as wellis.

Many political parties have been created out of these conservative Evangelical platforms, seeking to gain space in society through public expansion ${ }^{54}$. In most Latin American countries, neo-Pentecostal leaders have pene-

50 SEMÁN, Pablo. ¿Quiénes son? ¿Por qué crecen? ¿En qué creen? Pentecostalismo y política en América Latina. Revista Brasileira de Ciências Sociais, v. 34, n. 99, p. 26-45, 2019.

51 URUEÑA, Rene. Reclaiming the keys to the kingdom (of the World): evangelicals and human rights in Latin America. Netherlands Yearbook of International Law: Populism and International Law, p. 175-208, 2018.

52 URUEÑA, Rene. Reclaiming the keys to the kingdom (of the World): evangelicals and human rights in Latin America. Netherlands Yearbook of International Law: Populism and International Law, p. 175-208, 2018.

53 URUENA, Rene. Reclaiming the keys to the kingdom (of the World): evangelicals and human rights in Latin America. Netherlands Yearbook of International Law: Populism and International Law, p. 175-208, 2018.

54 SEMÁN, Pablo. ¿Quiénes son? ¿Por qué crecen? ¿En qué creen? Pentecostalismo y política en América Latina. Revista Brasileira de Ciências Sociais, v. 34, n. 99, p. 26-45, 2019. trated deep into the political gears. In addition, this movement has also presented itself as an interesting electorate for other pre-existing political parties. Populism appeared as a two-way bridge between the conservative Christian faithful and the right-wing politicians. This is how the fourth wave of populism has been prospering in Latin America ${ }^{55}$.

Evangelical political participation mainly occurs in three different fashions. Firstly, by an Evangelical party, a formal party led by a religious leader, under a religious mandate, seeking to reach governmental positions in order to evangelize the masses in Latin America. There are several cases of such new parties created from the Evangelical movement ${ }^{56}$.

Secondly, by an Evangelical front, a political front led by the faithful, but open to other people who share their political ideals ${ }^{57}$. Although the idea enjoys sympathy within the Evangelical community, it has not been sufficiently convincing the faithful that it is the best approach, as this front might reach a politician who is not necessarily Christian ${ }^{58}$.

Thirdly, by an Evangelical faction, in which religious leaders and the faithful participate in electoral processes within pre-existing political parties or movements. This third form of evangelical participation has been

55 BELLOLIO, Cristóbal. La cuarta ola de populismo latinoamericano. Revista Capital, sep. 2018. Available at: https://www.capital.cl/ la-cuarta-ola-de-populismo-latinoamericano/.

56 In Argentina, Partido Movimiento Reformador (PMR); in Costa Rica Partido Alianza Nacional Cristiana (PANC), Partido Renovación Costarricense (PRC) and Partido Restauración Nacional (PRN) - both countries in which Roman Catholicism is the official State's religion. In countries where there is a constitutional separation between State and Church, the new parties are equally existent: In Peru, Frente Evangelico (FE), Movimiento Acción Renovadora (AMAR), Unión Renovadora de Evangélicos Peruanos (EREP) and Partido Presencia Cristiana (PC); in the Dominican Republic, Partido Dominicano Podemos (PDP); in Guatemala, Frente de Convergencia Nacional (FCN Nación); in Bolivia, Organización Renovadora Autentica (ORA) and Alianza Renovadora Boliviana (ARBOL); in Chile, Alianza Nacional Cristiana (ANC) and in Colombia, as this article will explore further on, Aliança Nacional Cristiana, Partido Nacional Cristiano, Partido Movimiento Unión Cristiano, o Movimento Cívico Cristiano and Partido Cristiano de Transformación y Orden (PACTO). SILVA, Hélerson. Os novos atores "evangélicos" e a conquista do espaço público na América Latina. Reflexão, v. 43, n. 2, p. 243-263, 2018.

57 GUADALUPE, José Luis Pérez. Evangelicals and political power in Latin America. Lima: Konrad-Adenauer-Stiftung \& Institute of Social Christian Studies of Peru (IESC), 2019.

58 GUADALUPE, José Luis Pérez. Evangelicals and political power in Latin America. Lima: Konrad-Adenauer-Stiftung \& Institute of Social Christian Studies of Peru (IESC), 2019. 
the most prosperous option within Latin America's scenario. Although it does not depend on the communities gathering, the "faction" highlights a sense of belonging to a single group, as Evangelicals are pleased to participate in a political party that will provide them greater visibility. The other way around is also decisive - parties are even more pleased to have some representatives of the Evangelical movements in their ranks, knowing that they can expect these groups to join their electorate ${ }^{59}$.

Even though Evangelical movements organize by faction, their politics are not static, transforming and surging as time goes by. In Brazil, for example, the most powerful neo-Pentecostal groups supported Collor de Melo and Fernando Henrique Cardoso for presidency in the 1990's against the so called "communism danger" brought by the Labor Party (PT). Years later, they would support four elections won by left-wing PT candidates (Lula da Silva and Dilma Rousseff), moving to Marina Silva, a former minister of Lula. In 2018, they shifted again, and supported Jair Bolsonaro, a right-wing conservative candidate ${ }^{60}$.

Conservative Evangelical faithful do not necessarily vote in right-wing populists because their religious leader tells them to do so. They do it because they believe they are posing their own resistance to a threatening agenda ${ }^{61}$. The neo-Pentecostalism movement influences far beyond a ballot - it relies on cultural transformation in order to promote its growth. Therefore, the Evangelical faithful not only participate in the electoral politics and voting processes, but they have also turned into interlocutors of cultural changes and public policies ${ }^{62}$.

\subsection{LGBTI rights at stake}

The struggle with the LGBTI community was a key point in the shifting of the Evangelical mindset from "private" to "public". At the outset, Evangelicals did not openly challenge the group's existence, keeping this

\footnotetext{
99 GUADALUPE, José Luis Pérez. Evangelicals and political power in Latin America. Lima: Konrad-Adenauer-Stiftung \& Institute of Social Christian Studies of Peru (IESC), 2019.

${ }^{60}$ SEMÁN, Pablo. ¿Quiénes son? ¿Por qué crecen? ¿En qué creen? Pentecostalismo y política en América Latina. Revista Brasileira de Ciências Sociais, v. 34, n. 99, p. 26-45, 2019.

${ }^{61}$ SEMÁN, Pablo. ¿Quiénes son? ¿Por qué crecen? ¿En qué creen? Pentecostalismo y política en América Latina. Revista Brasileira de Ciências Sociais, v. 34, n. 99, p. 26-45, 2019.

${ }^{6}$ SEMÁN, Pablo. ¿Quiénes son? ¿Por qué crecen? ¿En qué creen? Pentecostalismo y política en América Latina. Revista Brasileira de Ciências Sociais, v. 34, n. 99, p. 26-45, 2019.
}

matter within the temple ${ }^{63}$. However, with the expansion of its activities and political influence, boosted by right-wing populists, the movement pushed for an understanding that their morality and ethics should prevail over the human rights agenda ${ }^{64}$. Neo-Pentecostal churches started moving from private to public sphere.

With the sexual orientation and gender identity debates in vogue, Evangelical sectors publicly set an opposing tone $\mathrm{e}^{65}$. They began to explicitly claim that their religious beliefs should occupy the public sphere, and their discourses should no longer be limited to private congregations and religious communities ${ }^{66}$.

LGBTI rights progressed considerably in the first decades of $21^{\text {st }}$ century, and as a result a conservative resistance started opposing LGBTI movements, hampering further progress ${ }^{67}$. Bringing together fundamentalist neo-Pentecostals and right-wring populists created a powerful burst of unprecedented ecumenism. These sectors, as well as sharing the same moral positions, believe that religious institutions should have a prominent role in the public sphere as a means to safeguard traditional values and protect society from moral decline ${ }^{68}$. They established a vertical connection that stretched from the highest government positions to thousands of faithful. The movement is transfixed in adoration of charismatic leaders whose aim is to purify public space, "othering" LGBTI communities and pointing to them as a foe of "the respectable citizen". This movement is dangerously fueling homophobia and transphobia

63 URUEÑA, Rene. Reclaiming the keys to the kingdom (of the World): evangelicals and human rights in Latin America. Netherlands Yearbook of International Law, Populism and International Law, p. 175-208, 2018.

${ }^{64}$ URUEÑA, Rene. Reclaiming the keys to the kingdom (of the World): evangelicals and human rights in Latin America. Netherlands Yearbook of International Law, Populism and International Law, p. 175-208, 2018.

65 CORRALES, Javier; PECHENY, Mario. Introduction: the comparative politics of sexuality in Latin America. In: CORRALES, Javier; PECHENY, Mario (org.). The politics of dexuality in Latin America. Pittsburgh: University of Pittsburgh Press, 2010. p. 1-30.

66 URUEÑA, Rene. Reclaiming the keys to the kingdom (of the World): evangelicals and human rights in Latin America. Netherlands Yearbook of International Law, Populism and International Law, p. 175-208, 2018.

67 CORRALES, Javier; PECHENY, Mario. Introduction: the comparative politics of sexuality in Latin America. In: CORRALES, Javier; PECHENY, Mario (org.). The politics of sexuality in Latin America. Pittsburgh: University of Pittsburgh Press, 2010. p. 1-30.

68 BELTRÁN, William Mauricio; CREELY, Sian. Pentecostals, gender ideology and the peace plebiscite: Colombia 2016. Religions, v. 9, 2018. 
through their public statements, as they claim LGBTI communities are a manifestation of irreligiosity - even though many LGBTI people are themselves religious ${ }^{69}$.

Right-wing populists and neo-Pentecostal leaders became vehicles of disinformation: an array of voices producing a cumulative echo chamber of homophobia and transphobia support ${ }^{70}$. Instead of "simply" opposing the LGBTI discourse, the movement climbs inside gender discussions, twisting theories, overdrawing facts, exploiting standards and rendering them absurd. Truth started to be regarded as a transitory, flexible concept which could be molded to suit populist-evangelical purposes $^{71}$.

In Colombia, religious-populism boosted anti-LGBTI narratives, which explains the warm reception of the political project of former right-wing President Alvaro Uribe within neo-Pentecostal circles $^{72}$. Uribe has been best able to take electoral advantage of the relevance and vitality of these traditional values in large sectors of Colombian society ${ }^{73}$. This strategy was especially relevant during the 2016 Colombian Peace Agreement referendum campaign.

\section{Colombian Peace Agreement Referendum: LGBTI rights caught in between the trenches}

\subsection{Setting the scene}

\footnotetext{
69 CORRALES, Javier; PECHENY, Mario. Introduction: the comparative politics of sexuality in Latin America. In: CORRALES, Javier; PECHENY, Mario (org.). The politics of dexuality in Latin America. Pittsburgh: University of Pittsburgh Press, 2010. p. 1-30.

${ }^{70}$ CORRALES, Javier. The expansion of LGBT rights in Latin America and the backlash. In: BOSIA, Michael; MCEVOY, M. Sandra; RAHMAN, Momin (org.). The Oxford handbook of global LGBT and sexual diversity politics. 2019.

71 CORRALES, Javier. The expansion of LGBT rights in Latin America and the backlash. In: BOSIA, Michael; MCEVOY, M. Sandra; RAHMAN, Momin (org.). The Oxford handbook of global LGBT and sexual diversity politics. 2019.

72 BELTRÁN, William Mauricio; QUIROGA, Jesús. Pentecostalismo y política electoral en Colombia (1991-2014). Colombia Internacional, v. 91, p. 187-212, 2017.

73 BELTRÁN, William Mauricio; CREELY, Sian. Pentecostals, gender ideology and the peace plebiscite: Colombia 2016. Religions, v. 9, 2018.; RONDÓN, Manuel Alejandro Rodríguez. La ideología de género como exceso: pánico moral y decisión ética en la política colombiana. Sexualidad, Saludy Sociedad, Rio de Janeiro, n. 27, p. 128148, 2017.
}

In 2016, Colombians thought the fifty-year war which had bled the country out would finally be over. After four years of intense negotiations between the government and the left-wing armed group Revolutionary Armed Forces of Colombia- People's Army (hereinafter FARC-EP), achieving a lasting peace had never been so tangible. On 24 August 2016, the news spread that an Integral Agreement to end the conflict and build a transitional justice process had finally been reached. Three months later, the Final Peace Agreement (Acuerdo Final de Paz) was signed in Teatro Colón, in the city of Bogotá. However, a lot happened in those three months.

The then president, Juan Manuel Santos, convened a national referendum, calling on Colombians to endorse what was one of the greatest peace accomplishments of this century. Against all the prognostics, on the $2^{\text {nd }}$ October 2016, the "no" vote won by a narrow margin: $50.21 \%$ of Colombians decided to reject the Integral Agreement ${ }^{74}$. Experts were caught by surprise and the international community was appalled. Public expectations were crushed. The success of the "no" vote triggered political uncertainty in Colombia. During the negotiations, more than $70 \%$ of Colombians approved the process. Apart from the Centro Democrático, led by the former president Alvaro Uribe, all other parties and most Colombian political personalities were in favor of the agreement. It also enjoyed wide support among the media, academia and cultural spheres ${ }^{75}$. What could have undermined the predicted positive outcome? Understanding what happened on the $2^{\text {nd }}$ October requires digging into right-wing populism, neo-Pentecostal movements, and the gender panic set up by them.

Many factors influenced the success of the "no" $\operatorname{vote}^{76}$. However, the recognition of LGBTI rights and the incorporation of a "gender focus" (enfoque de género) in the Agreement was one key reason why voters rejected the product of years of negotiations $\mathrm{s}^{77}$. Behind

\footnotetext{
74 Just $37 \%$ of the electorate casted a vote.

BASSET, Yann. Claves del rechazo del plebiscito para la paz en Colombia. Estudios Políticos, Medellín, v. 52, p. 241-265, 2017.

76 Beyond the matters related to gender identity and sexual orientation, the "no" supporters also requested that those found guilty of crimes be barred from running for public office; that the FARC-EP leaders served time in prison for the crimes committed; and that the FARC-EP used their illicit gains to pay victims' compensation. BBC NEWS. Colombia Farc conflict: Uribe says peace deal was 'weak' after Santos meeting. BBC News, out. 2016. Available at: https:// www.bbc.com/news/world-latin-america-37558825.
}

77 ESPITIA, Monica. LGBT in Colombia: a war within. CUNY 
this result, a campaign led by the neo-Pentecostal Evangelical church and backed by the former president Uribe, claimed that the "yes" vote would imply modifying essential Colombian institutions such as marriage, family and adoption.

\subsection{How did we get there?}

The armed conflict between the Colombian government and the FARC-EP started in 1964, when the left-wing group was constituted with the aim of overthrowing the government and installing a Marxist regime through armed struggle ${ }^{78}$. The country faced a deeply unequal distribution of land, power, and wealth, and the FARC-EP claimed to be fighting for social justice. The State responded by waging a deadly war against the armed group. In parallel, paramilitary forces were established, with help and support from parts of the government, to oppose the FARC-EP. In order to finance its armed campaign, by the 1990s the FARC-EP began to develop links with the drug business and engaged in kidnappings and extortions. Although the FARC-EP enjoyed a considerable amount of popular support at the outset, these illegal activities associated with acts of violence against the civilian population resulted in a considerable loss of its public approval ${ }^{79}$.

Fluctuating between higher and lower levels of violence, changing leadership, and passing through contrasting phases, the fifty-two years of conflict were devastating and ripped Colombia apart. More than 220,000 killings have been registered, 100,000 people were victims of forced disappearance and there were thousands of incidences of kidnappings and sexual violence. The bloodshed, persecution and brutality forced almost 40 million people to flee their homes ${ }^{80}$.

The LGBTI population was caught up in this situa-

\footnotetext{
Academic Works, 2016. Available at: https://academicworks.cuny. edu/gi_etds/150.

78 BELLAL, Annyssa. The war report: armed conflicts in 2016. Geneva Academy of International Humanitarian Law and Human Rights, 2017. Available at: https://ssrn.com/abstract $=30858$.

79 BELLAL, Annyssa. The war report: armed conflicts in 2016. Geneva Academy of International Humanitarian Law and Human Rights, 2017. Available at: https://ssrn.com/abstract $=30858$.

80 At the time of the referendum, Colombia had about 6 million internally displaced people (IDP), number only exceeded by Syria. MALDONADO, Andrés Ucrós. What is the colombian peace process teaching the world?. New England Journal of Public Policy, v. 29, n. 1, 2017.
}

tion. Beyond the discrimination of a largely homophobic and transphobic society ${ }^{81}$, the LGBTI community has also been specifically targeted by the Colombian armed forces, the FARC-EP and the paramilitary ${ }^{82}$.

Violence from the government and the FARC-EP was ruthless, and at times putting an end to the conflict seemed utopic. Throughout the years, several attempts to hold peace talks and negotiations between the government and the FARC-EP were advanced. Although different degrees of success were achieved, economic factors, foreign policy alliances and the lack of proper articulation hindered the conclusion of a peace accord. In 2012, these circumstances changed, and the negotiations had the wind in its sails. Both parties realized peace was costly, but the costs of not reaching an agreement would continue to be insurmountable ${ }^{83}$.

\subsection{Gender focus in armed conflicts and peace agreements}

81 Specific forms of violence are perpetrated against the different members of the LGBTI community. In Colombia, it should be highlighted the innumerable cases of "corrective rape" against lesbians and trans women, well documented by the Interamerican Commission of Human Rights. Inter-American Commission on Human Rights. INTER-AMERICAN COMMISSION OF HUMAN RIGHTS. Violence against LGBTI persons in the Americas. Washington, DC: Inter-American Commission on Human Rights, 2015. para. 279,345 .

82 During the conflict, LGBTI individuals were four times more likely than cis- and straight people to be threatened and abused by the mentioned actors. The military and police forces organized raids, arbitrary detentions, torture, sexual harassment and expulsion of LGBTI groups from public places. The FARC-EP commanders stigmatized LGBTI people as HIV carriers, and ousted the fighters to their families, also displacing them from the demilitarized zone. Testimonies of LGBTI individuals revealed that paramilitary groups subjected gay men and transgender women to participate in boxing competitions as a form of public humiliation and distributed pamphlets that promised to cleanse towns from "undesired members of society," which included drug addicts, criminals and members of the LGBTI community. The hardships experienced by LGBTI communities in the Colombian conflict did not stop there. Because of stigmatization and fear due to the lack of guarantees, victims remain silent and what exactly happened and how many are them is imprecise. Moreover, data on violence against the LGBTI community during the armed conflict is scarce, as there are flaws and shortcomings of record keeping. The Colombian Victims' Unit has registered close to 1,800 victims, which covers just the last four years of the conflict. Prior to 2012, the sexual orientation and gender identity of the victims was not computed. ESPITIA, Monica. LGBT in Colombia: a war within. CUNY Academic Works, 2016. Available at: https:/ / academicworks.cuny.edu/gj_etds/150.

83 BATTAGLINO, Jorge; LODOLA, Germán. Negotiations and possible spoilers in the Colombian peace process. Norwigian Peace Building Resource Center, Expert Analysis, 2013. 
The Peace Agreement had five points, all underscored by "gender focus" ${ }^{\text {". }}$. LGBTI rights were considered for the first time ever in a peace process: the disproportionate persecution against LGBTI people was finally recognized by both the government and the FARC-EP.

But LGBTI rights were not always entangled with the peace process. Only after two years of negotiations, giving way to the pressure exerted by the social movements, that a Subcommission on Gender was created. However, women's issues were the primary topic of the Subcommission, and LGBTI's simply embarked on their track. On the LGBTI front, the goal was to incorporate victims' testimonies and LGBTI rights in the Agreement, turning violations into operative provisions ${ }^{85}$.

The developments were a follow-up of an international push (later adopted by Colombian civil society) for acknowledging women's rights and gender awareness in armed conflicts and peace processes. The gender sensitiveness of the Integral Peace Agreement reflected the achievements in the international aren ${ }^{86}$. Women's rights movements achieved important landmarks before the Committee on the Elimination of Discrimination Against Women, the Rome Statute, and United Nations Security Council ${ }^{87}$. All these instances recognized the disproportionate effect of armed conflicts on women ${ }^{88}$.

International law is less well developed in the area of LGBTI rights. However, over the last decade, LGBTI has caught the women's rights ride, and queer len-

\footnotetext{
84 In Habana, the negotiators set the general architecture of the peace plan, with five points entailing rural reform; a framework for political participation of the FARC-EP; illicit drugs; end of conflict and decommission; and victims and post-war justice.

85 CÉSPEDES-BÁEZ, Lina M. Gender panic and the failure of a peace agreement. AJIL Unbound, v. 110, p. 183-187, 2016.

86 Victims' rights and past quarrels are often neglected during peace negotiations. Because they are sensitive topics, it is not uncommon that they are left to future political debate not to "contaminate" the peace process with "matters of justice". This is counter-productive: leaving demands of justice unhealed brings only a relative and short-lived peace. The Colombian peace process has directly challenged the idea that justice and peace are contradictory and the Subcommission on Gender is a case in point. BATTAGLINO, Jorge; LODOLA, Germán. Negotiations and possible spoilers in the Colombian peace process. Norwigian Peace Building Resource Center, Expert Analysis, 2013.

87 MARGALIT, Alon. Still a blind spot: the protection of LGBT persons during armed conflict and other situations of violence. International Review of the Red Cross, v. 100, n. 907-909, p. 237-265, 2018. 88 CÉSPEDES-BÁEZ, Lina M. Gender panic and the failure of a peace agreement. AJIL Unbound, v. 110, p. 183-187, 2016.
}

ses have been increasingly used to analyze issues arising from warfare. It has become part of the gender-based reading of conflict. Reports from the Human Rights Council, the Office of the United Nations High Commissioner for Human Rights, and the United Nations Secretary General have demonstrated the suffering of LGBTI people during armed conflicts ${ }^{89}$. In 2015, the United Nations Security Council debated for the first time LGBTI rights, and the organization acknowledged the attacks against them as a form of "moral cleansing"90. Additionally, in 2016 the organization's General Assembly affirmed that the use of lethal force on the basis of real or perceived sexual orientation or gender identity constitutes arbitrary deprivation of the right to life ${ }^{91}$. On the same strand, scholars have been arguing that warfare and militarization favors hegemonic masculinities, gender hierarchies and normative heterosexuality ${ }^{92}$. As a result, these phenomena are channeled into violence and discrimination against LGBTI groups ${ }^{93}$.

The Colombian Integral Peace Agreement is a pioneer in acknowledging LGBTI rights. However, it does not go further than what had already been discussed in the international and domestic scene. Most points of the agreement were limited to describing LGBTI groups as a part of reality, and failed to operationalize the provisions to the specificities of LGBTI rights and needs ${ }^{94}$.

89 MARGALIT, Alon. Still a blind spot: the protection of LGBT persons during armed conflict and other situations of violence. International Review of the Red Cross, v. 100, n. 907-909, p. 237-265, 2018.

90 THYLIN, Theresia. Violence, toleration, or inclusion? Exploring variation in the experiences of LGBT combatants in Colombia. Sexualities, v. 23, p. 1-20, 2019. MYRTTINEN, Henri; DAIGLE Megan. When merely existing is a risk: sexual and gender minorities in conflict, displacement and peacebuilding. London: International Alert, 2017.; GOLDSTEIN, Joshua S. War and gender: how gender shapes the war system and vice versa. Cambridge: Cambridge University Press, 2001.

91 UNITED NATIONS GENERAL ASSEMBLY. Resolution. 71/198, 19 December 2016, para. 6; HUMAN RIGHTS COUNCIL. Report of the Special Rapporteur on Extrajudicial, Summary or Arbitrary Executions on a Gender-Sensitive Approach to Arbitrary Killings. UN Doc. A/HRC/ 35/23, June 2017, paras 45, 47-48.

92 MARGALIT, Alon. Still a blind spot: the protection of LGBT persons during armed conflict and other situations of violence. International Review of the Red Cross, v. 100, n. 907-909, p. 237-265, 2018. 93 THYLIN, Theresia. Violence, toleration, or inclusion? Exploring variation in the experiences of LGBT combatants in Colombia. Sexualities, v. 23, p. 1-20, 2019.

94 Throughout the document, sexual orientation and gender identity are used as a category, together with ethnicity and age group. CÉSPEDES-BÁEZ, Lina M. Gender panic and the failure of a peace agreement. AJIL Unbound, v. 110, p. 183-187, 2016. 
Also, "gender" ended up as the embodiment of the cis-straight women's experiences, whilst sexual orientation and gender identity were left aside ${ }^{95}$. Also, within the LGBTI community, there is an uneven level of marginalization. The different threats posed to different members of the group were not identified and LGBTI was portrayed as a uniform body. This demonstrates the embryonic and contested state of LGBTI knowledge within armed conflict and transitional justice.

Nothing in the agreement indicates that it bolstered more than legitime LGBTI rights, rooted in international understandings. However, the conservative movement, prompted by the right-wing populist Uribe, and neo-Pentecostal evangelical leaders, perceived it as highly upsetting to traditional values. This occurred in a context where, in a relatively short period of time, abortion was partially decriminalized in Colombia, equal marriage was recognized, same-sex couples were authorized to adopt, and transgender people could modify their name and sex on their identity documents without requiring the intervention of the judiciary. Discrimination based on gender identity and sexual orientation was criminalized and LGBTI people could finally be recognized as victims of the armed conflict and, therefore, be access reparations ${ }^{96}$. The scarce victories of the LGBTI movement in the agreement were regarded as the last straw and spurred gender panic in Colombia. The referendum presented a stage for anti-LGBTI forces to disseminate their homophobia and transphobia.

\subsection{The $2^{\text {nd }}$ October 2016 referendum}

The government and the FARC-EP hammered out a 297-page document, agreeing on a variety of matters, including transitional justice, the fight against impunity,

\footnotetext{
95 For example, on the point regarding rural reform, gender stands for general category. Further in, gender echoes a binary perspective and is translated mostly into concrete measures to benefit women. Similarly, on the point regarding political participation, women's rights were highlighted, and the importance of their political participation to build strong democratic societies was recognized. This point stands out, as it entails an explicit commitment to promote the LGBTI social movement and fight LGBTI stigmatization. CÉSPEDES-BÁEZ, Lina M. Gender panic and the failure of a peace agreement. AJIL Unbound, v. 110, p. 183-187, 2016.

96 RONDÓN, Manuel Alejandro Rodríguez. La ideología de género como exceso: pánico moral y decisión ética en la política colombiana. Sexualidad, Salud y Sociedad, Rio de Janeiro, n. 27, p. 128148, 2017.
}

and victims' rights ${ }^{97}$. With difficulties and sensitivities, after years of negotiation, the agreement was finally ready. Nothing in the accord indicated the requirement of a referendum to take place, but president Santos understood voting would be paramount to cement popular support for the agreement. The polls were predicting the accord would easily pass, envisioning a comfortable victory for the "yes" vote ${ }^{98}$. Every aspect of public life during the week of the referendum had been designed to represent the end of Colombia's oldest war: everyone wore white; groups of women and children sang songs of peace; Manuel Santos and Timochenko, FARC-EP's leader, gave touching speeches ${ }^{99}$. Santos was confident of a positive result and might have underestimated one part of his own "sandwich": the right-wing populists.

Behind the narrow victory of the "no" vote, two main actors can be identified: the neo-Pentecostal Evangelical church and the Senator and former President Álvaro Uribe Vélez, which led a right-wing populist movement. These actors blended into a conservative voice, which was instrumental in defeating the "yes" vote in referendum. They campaigned against the content of the agreement, as it allegedly threatened Colombian values, such as the biological difference between man and woman, the traditional family, and the place of religion in public life ${ }^{100}$. Some even claimed the Integral Agreement upheld a "homodictatorship", and the document, corrupted by "gender ideology", would advance the "homosexualization" of millions of Colombians" ${ }^{101}$.

\subsection{Right-wing populism and the neo- Pentecostal Evangelical church}

97 TATE, Winifred. A dark day in Colombia. Nacla, oct. 2016. Available at: https://nacla.org/news/2016/10/04/dark-day-colombia- 0 .

98 TATE, Winifred. A dark day in Colombia. Nacla, oct. 2016. Available at: https://nacla.org/news/2016/10/04/dark-day-colombia- 0 .

99 ANDERSON, Jon Lee. How Colombia's voters rejected peace. The New Yorker, oct. 2016. Available at: https://www.newyorker. $\mathrm{com} /$ news/daily-comment/how-colombias-voters-rejected-peace.

100 VÉLEZ, Juanita. El Sí pierde un aliado por "la familia". La Silla Vacia, aug. 2016. Available at: http://lasillavacia.com/historia/ el-si-pierde-un-aliado-por-la-familia-57572.; CÉSPEDES-BÁEZ, Lina M. Gender panic and the failure of a peace agreement. AJIL Unbound, v. 110, p. 183-187, 2016.

101 It is necessary to highlight that not all leaders or sectors of Colombian Protestantism share these opinions. BELTRÁN, William Mauricio; CREELY, Sian. Pentecostals, gender ideology and the peace plebiscite: Colombia 2016. Religions, v. 9, 2018. 
Colombia's former two-term President Álvaro Uribe is one of most important political figures in the country ${ }^{102}$. During his presidency his popularity reached levels that ranged from 60 to $70 \%$. His power did not cease with the end of his mandate as President: currently, Uribe is linked to the Centro Democrático party, and in 2014 became a Senator, being the most voted for politician for this position in Colombian history.

Uribe is a populist, far-right leader. He employs a straightforward, direct, popular, moralistic and extremely manicheistic political discourse. He embodies the people's fight against an imaginary foe, and his way of making politics is always under the view of moral and upfront struggle against an adversary ${ }^{103}$. Dialogue and negotiation are secondary. Uribe's approach to politics is guiding the country with an iron first, and in $2001 \mathrm{du}-$ ring his presidential electoral campaign, security was his fundamental pillar. He claimed he would strengthen the treatment given to "internal enemies" and recover lost sovereignty in parts of the country's territory. Uribe's narrative complied with the idea of "othering", so present in populist movements.

During the peace negotiations, he supported a strong-arm approach to ending the conflict, insisting that Santos' deal was too lenient on the armed group ${ }^{104}$. "We want peace, but not this peace" was his slogan. By endorsing the "no" vote, Uribe claimed that he did not support continued war but wanted a better agreement. "Colombians, let's correct the path", he stated after the final result was revealed ${ }^{105}$.

Uribe used Twitter as his main platform. During the

\footnotetext{
102 It is interesting that Santos and Uribe were once allies. Santos founded Uribe's party, Centro Democrático, and when Uribe served as president, from 2002 to 2010, Santas was the minister of defense. When Santos became president and revealed that he had begun peace negotiations with the FARC-EP, Uribe accused him of betrayal. ANDERSON, Jon Lee. How Colombia's voters rejected peace. The New Yorker, oct. 2016. Available at: https://www.newyorker. $\mathrm{com} /$ news/daily-comment/how-colombias-voters-rejected-peace. 103 FIERRO, Marta, C. Alvaro Uribe populism and neo-populism. Análisis politico, Bogotá, v. 27, n. 81, p. 127-147, mayo/ago. 2014.

104 CYR, Jennifer; MELÉNDEZ, Carlos. Colombia’s right-wing populist movement defeated the peace deal: here's how we know. The Washington Post, oct. 2016. Available at: https://www.washingtonpost.com/news/monkey-cage/wp/2016/10/04/colombiasright-wing-populist-movement-defeated-the-peace-deal-heres-howwe-know/.

105 BRODZINSKY, Sibylla. Colombia referendum: voters reject peace deal with Farc guerrillas. The Guardian, oct. 2016. Available at: https://www.theguardian.com/world/2016/oct/02/colombiareferendum-rejects-peace-deal-with-farc.
}

referendum campaign, he reacted to news, argued with other politicians and journalists, and generally spread fake news multiple times a day ${ }^{106}$. He used social media to attack Santos and the FARC-EP, lumping them together, and jeopardizing the peace deal. Uribe claimed the peace agreement was akin to Colombia "handing over the country" to "castrochavistas" 107 . In an insulting tone, he claimed the reconciliation with the FARC would drive Colombia towards becoming the next Cuba or Venezuela ${ }^{108}$.

It is easy to draw a parallel between the United States of America's president and epitome of populism, Donald Trump, and Uribe's deployment of social media, in his reactionary tone, populist rhetoric, and the combative slogans ${ }^{109}$. Further, some similarities between the triumph of the "No" vote, Brexit and the election of Trump, (all of which took place in 2016) can be drawn. The main points of intersection are the populist discourses, the strategic use of social media and the circulation of 'fake news' in the campaigns ${ }^{110}$.

Also known as Uribistas, Uribe's followers regarded the developments established in the peace accord as a threat ${ }^{111}$. They campaigned against the promotion of a "confused gender ideology" enshrined in the document ${ }^{112}$. Pamphlets promoting the "no" vote read, "Colombia is in danger of falling under the control of a communist dictatorship and the imminent passage of a

106 KRYSTALLI, Roxanne; THEIDON, Kimberly. Here's how attention to gender affected Colombia's peace process. The Washington Post, oct. 2016. Available at: https://www.washingtonpost.com/ news/monkey-cage/wp/2016/10/09/heres-how-attention-to-gender-affected-colombias-peace-process/.

107 Referring to Marxists who support Fidel Castro and Chavismo. 108 TATE, Winifred. A dark day in Colombia. Nacla, oct. 2016. Available at: https://nacla.org/news/2016/10/04/dark-day-colombia- 0 .

109 ANDERSON, Jon Lee. How Colombia's voters rejected peace. The New Yorker, oct. 2016. Available at: https://www.newyorker. $\mathrm{com} /$ news/daily-comment/how-colombias-voters-rejected-peace.

110 BELTRÁN, William Mauricio; CREELY, Sian. Pentecostals, gender ideology and the peace plebiscite: Colombia 2016. Religions, v. 9, 2018.

111 The Uribistas became a political wave represented in the Democratic Center Party. Although the party has "centre" in its name, the party is renowned for its extreme right-wing stance and policies. GRATTAN, Steven. The emerging challenges and opportunities for the LGBT+ population in post-accord Colombia. Thesis for: MA Human Rights and Global Ethics. Universidad del Rosario, 2018.

${ }_{112}$ KRYSTALLI, Roxanne; THEIDON, Kimberly. Here's how attention to gender affected Colombia's peace process. The Washington Post, oct. 2016. Available at: https://www.washingtonpost.com/ news/monkey-cage/wp/2016/10/09/heres-how-attention-to-gender-affected-colombias-peace-process/. 
gender ideology ${ }^{113}$ ". During the campaign, a new group emerged, the National Movement of the Family. It described itself as "neither political nor religious", but its objective is to "fight in favor of God's original design for the family and thus for the moral bases that allow us to construct our society". Uribe praised these views on Twitter: "saying that one is not born female or male, but that this is defined by 'society,' is an abuse of minors, a disrespect of nature and of the family."

Influenced by Uribe's disinformation campaign, a considerable part of the neo-Pentecostal leadership concluded that the LGBTI community was using "the agreement as a platform to promote their political projects" 114 . On the day the Integral Agreement was announced by Santos and Timochenko, Uribe appeared in Cartagena holding hands with Miguel Arrázola, one of the pastors who later, during the "no" campaign, publicly pushed the rejection of the agreement. Right after the success at the polls on the 2nd October 2016, Uribe reiterated the need to encourage family values defended by religious leaders and moral pastors ${ }^{115}$. The Senator's relationship with evangelical groups had always been apparent, but during the campaign their closeness was exacerbated ${ }^{116}$.

It is undeniable that the "no" vote is a victory of the Uribistas. But it is not a victory of the Uribistas alone: the whole neo-Pentecostal machinery was put at the disposal of the movement, thereby influencing and mobilizing the faithful ${ }^{117}$. At the time of the referendum,

113 TATE, Winifred. A dark day in Colombia. Nacla, oct. 2016. Available at: https://nacla.org/news/2016/10/04/dark-day-colombia- 0 .

114 MORENO, Pablo. Panorama general sobre la acción social de las iglesias evangélicas en Colombia 1990-2005. Bogotá: CEDECOL, 2009; BELTRÁN, William Mauricio; CREELY, Sian. Pentecostals, gender ideology and the peace plebiscite: Colombia 2016. Religions, v. 9, 2018.

115 VÉLEZ, Juanita. Santos le quita fe a Uribe. La Silla Vacía, aug. 2016. Available at: https://lasillavacia.com/historia/santos-le-quitafe-uribe- 58243.

116 Cristianos: ¿el poder decisorio en la política? Semana, oct. 2016. Available at: http://www.semana.com/nacion/articulo/religioninclina-la-balanza-politica-en-colombia/502530.

117 The Catholic Church also has some responsibility over the result, as it has never compromised itself with the 'yes', At the outset, they supported negotiating a solution to the conflict and the peace process, but did not promote the "yes" vote. COSOY, Natalio. El rol de las iglesias cristianas evangélicas en la victoria del "No" en el plebiscito de Colombia. BBC News, oct. 2016. Available at: https:// www.bbc.com/mundo/noticias-america-latina-37560320.; BASSET, Yann. Claves del rechazo del plebiscito para la paz en Colombia. Estudios Politicos, Medellín, v. 52, p. 241-265, 2017.
neo-Pentecostal Evangelical movements in Colombia were spearheaded by seven main personalities ${ }^{118}$, all of them were active in the "no" campaign. What is more, all of them publicly declared their alignment with the political project of Álvaro Uribe ${ }^{119}$. In Colombia, many neo-Pentecostal leaders have identified with Uribe's authoritarian and paternalistic fashion, and his conservative position in matters of morality, sexuality and family. Uribe knew how to capitalize on this relationship.

The rejection of the agreement was considered "a miracle" by the neo-Pentecostal leaders ${ }^{120}$. The triumph of the "no" vote was possible because of the evangelical factor, whose leaders openly antagonized the peace agreements ${ }^{121}$. The so-called 'gender ideology' was adopted as strategy to advocate for the "no" campaign. ${ }^{122}$. Depending on the convenience and the context, con-

118 These personalities were Cesar and Claudia Castellanos (of the Misión Carismática Internacional which has churches in major cities all over the country); pastor Eduardo Cañas (from Manantial de Vida Eterna in Bogotá); pastor Jorge Trujillo (from Centro Cristiano Casa del Reino in Bogotá); pastor John Milton Rodríguez (from the Misión Paz a las Naciones en Cali); pastor Miguel Arrázola (from the Ríos de Vida church in Cartagena and Barranquilla); pastor Marco Fidel Ramírez (also a City Councillor in Bogotá, self-proclaimed 'Councillor for the family'); and Ángela Hernández (representative in the regional government of Santander).

119 COSOY, Natalio. El rol de las iglesias cristianas evangélicas en la victoria del "No" en el plebiscito de Colombia. BBC News, oct. 2016. Available at: https://www.bbc.com/mundo/noticias-americalatina-37560320; VÉLEZ, Juanita. El Sí pierde un aliado por "la familia”. La Silla Vacia, aug. 2016. Available at: http://lasillavacia. com/historia/el-si-pierde-un-aliado-por-la-familia-57572; PRIETO, Jineth; LEÓN, Ana. El poder de la fe que le apunta al No. La Silla Vacia, sep. 2016. Available at: http://www.lasillavacia.com/historia/ el-poder-de-la-fe-que-le-apunta-al-no-58150; BELTRÁN，William Mauricio; CREELY, Sian. Pentecostals, gender ideology and the peace plebiscite: Colombia 2016. Religions, v. 9, 2018.

120 Cristianos: ¿el poder decisorio en la política? Semana, oct. 2016. Available at: http://www.semana.com/nacion/articulo/religioninclina-la-balanza-politica-en-colombia/502530.; BELTRÁN, William Mauricio; CREELY, Sian. Pentecostals, gender ideology and the peace plebiscite: Colombia 2016. Religions, v. 9, 2018.

121 RONDÓN, Manuel Alejandro Rodríguez. La ideología de género como exceso: pánico moral y decisión ética en la política colombiana. Sexualidad, Saludy Sociedad, Rio de Janeiro, n. 27, p. 128148, 2017.; SERRANO, Alfredo. El fenómeno cristiano detrás del No. El Espectador, oct. 2016. Available at: http: //www.elespectador. $\mathrm{com} /$ noticias/politica/el-fenomeno-cristiano-detras-del-no-articulo-661678.; VELASCO, Juan David. Colombia: de minorías dispersas a aliados estratégicos. In: PÉREZ, José Luis; GRUNDBERGER, Sebastian (org.). Evangélicos y poder en América Latina. Lima: KAS \& IESC, 2018. p. 221-245.

122 BELTRÁN, William Mauricio; CREELY, Sian. Pentecostals, gender ideology and the peace plebiscite: Colombia 2016. Religions, v. 9, 2018.; SEGURA, Hugo García. Colombia justa-libres, la apuesta electoral cristiana. El Espectador, oct. 2017. Available at: https:// www.elespectador.com/noticias/politica/colombia-justa-libres- 
servative activism associated gender ideology to atheists, communists, homosexuals, feminists, defenders of a non-military solution to the armed conflict, "gay lobby", "abortionists" and "Castro-Chavismo". What would join them together would be their anti-community. Hence, they would constitute the nation's enemy ${ }^{123}$.

During the referendum campaign, neo-Pentecostal megachurches used their influence to persuade pulpits to support the "no" vote ${ }^{124}$. Their organizational infrastructure, which entailed auditoriums, printing presses, schools, mass media, presence in radio stations, and television programs were put at the service of the campaign machinery. Thus, these megachurches became stages for political proselytizing.

The neo-Pentecostal gears were used to spread fake news, creating an anti-LGBTI paranoia and even affirming the document had been "agreed with witchcraft" 125 . By portraying a superficial understanding of feminist and queer theory, and misrepresenting the gender focus in the agreement ${ }^{126}$, they depicted the fight against gender ideology as a battle between the "corrupt" feminists and LGBTI activists, on the one hand, and "pure" citizen-believers on the other. This narrative was highly characterized by the populist reasoning, which exacerbates an "us. vs them" feeling.

la-apuesta-electoral-cristiana-articulo-720411.; VELASCO, Juan David. Colombia: de minorías dispersas a aliados estratégicos. In: PÉREZ, José Luis; GRUNDBERGER, Sebastian (org.). Evangélicosy poder en América Latina. Lima: KAS \& IESC, 2018. p. 221-245.

123 RONDÓN, Manuel Alejandro Rodríguez. La ideología de género como exceso: pánico moral y decisión ética en la política colombiana. Sexualidad, Saludy Sociedad, Rio de Janeiro, n. 27, p. 128148, 2017.

124 The campaign was also broadcasted in small churches, but the phenomenon gained a unique dimension at the megachurches, which are generally found in large cities and are common within Pentecostalism. BELTRÁN, William Mauricio; CREELY, Sian. Pentecostals, gender ideology and the peace plebiscite: Colombia 2016. Religions, v. 9, 2018.

125 EL ESPECTADOR. Para Marco Fidel Ramírez, Colombia será "ateo-marxista y homosexual" tras firma de paz. El Espectador, sep. 2016. Available at: http://www.elespectador.com/noticias/bogota/ marco-fidel-ramirez-colombia-sera--ateo-marxista-y-homos-articulo-656908.; LAS OCHO peticiones de los pastores del No. Semana, oct. 2016. Available at: http://www.semana.com/nacion/articulo/ las-ocho-peticiones-de-los- -pastores-que-votaron-no-en-el-plebiscito/499219.

126 CEPEDA, Álvaro. Clientelismo y fe: dinámicas políticas del pentecostalismo en Colombia. Bogotá: Editorial Bonaventuriana, 2007; BELTRÁN, William Mauricio; CREELY, Sian. Pentecostals, gender ideology and the peace plebiscite: Colombia 2016. Religions, v. 9, 2018; BELTRÁN, William Mauricio; QUIROGA, Jesús. Pentecostalismo y política electoral en Colombia (1991-2014). Colombia Internacional, v. 91, p. 187-212, 2017.

\subsection{The post-referendum}

After the referendum, the peace process was left in limbo. The then president Manuel Santos affirmed that he would continue meeting opponents to try to rescue the deal - which he did, but at the expense of the LGBTI community. Santos convened the Grand National Dialogue (Gran Diálogo National), which aimed to change, adjust and clarify the Integral Agreement into what would later be the Final Agreement to be signed at the National Congress.

He met with the two sides of what the present paper considers as Latin America's "new sandwich". First, he talked to several pastors, in order to discuss the importance of the so-called traditional family in the peace process. He mentioned he was "able to explain that the process does not promote gender ideology. It recognizes and defends women's role as victims and peacemakers" 127 . By this statement, it can be inferred that LGBTI rights were completely forgotten. Then, he met with Uribe to try to soften the right-wing populist's followers ${ }^{128}$.

The "no" campaigners proposed forty-four changes to the Integral Agreement, which included the adoption of a concept of the family as the union of a man and a woman", the elimination of expressions such as "diverse gender identity" and "diverse sexual orientation", the inclusion of family as a "fundamental nucleus of society", and the recognition of religious people as victims of the conflict. ${ }^{129} \mathrm{Neo}$-Pentecostal leaders insisted on removing every gender and sexual identity aspect of the agreement, and proposed to simply promote women's rights ${ }^{130}$. These changes were then negotiated with the

127 EL ESPECTADOR. El acuerdo con las Farc no promueve la ideología de género": Santos. El Espectador, oct. 2016. Available at: https://www.elespectador.com/noticias/politica/el-acuerdo-farcno-promueve-ideologia-de-genero-santos-articulo-660110.

128 BBC NEWS. Colombia Farc conflict: Uribe says peace deal was 'weak' after Santos meeting. BBC News, oct. 2016. Available at: https://www.bbc.com/news/world-latin-america-37558825.

129 VÉLEZ, Juanita. Cristianos y LGBTI: ambos sienten que ganaron con el acuerdo. La Silla Vacia, nov. 2016. Available online: http://lasillavacia.com/historia/cristianos-y-Lgbti-ambos-sientenque-ganaron-con-el-acuerdo-58838; BELTRÁN, William Mauricio; CREELY, Sian. Pentecostals, gender ideology and the peace plebiscite: Colombia 2016. Religions, v. 9, 2018.

130 VÉLEZ, Juanita. Cristianos y LGBTI: ambos sienten que ganaron con el acuerdo. La Silla Vacía, nov. 2016. Available online: http://lasillavacia.com/historia/cristianos-y-Lgbti-ambos-sientenque-ganaron-con-el-acuerdo-58838; BELTRÁN, William Mauricio; CREELY, Sian. Pentecostals, gender ideology and the peace plebi- 
FARC-EP leaders. Although LGBTI rights were not completely discarded, they were softened. The gender focus turned out to be defined in a binary fashion, as the recognition of equal rights between men and women, and a semantic war managed to reduce the use of the word "gender" in the document from 144 to 55 times. Mentions of sexual orientation and gender identity were removed. However, the Catatumbo clause remained ${ }^{131}$, and the neo-Pentecostal's most important request was not achieved, which was to replace the gender approach with a women's rights approach ${ }^{132}$.

The Final Peace Agreement yielded to moralistic discourses and the fear of a "pink tide" spread by the right-wing populist Alvaro Uribe and conservative religious sectors. In this sense, during the Grand National Discourse, LGBTI rights were toned down to appease the Colombian society's gender panic. According to the LGBTI activist Germán Humberto Rincón "Yes, they named us in the agreement, but they belittled us. Better said, they won and we lost, because churches were given too much space $[\ldots]]^{\prime 133}$.

\section{Conclusion}

The moralization of politics is a global phenomenon. The idea of moral panic, and more specifically, panic against "gender ideology" is convenient in building a nation's enemy. The fear of transforming the structures of homophobia and transphobia has been appropriated by a political project rooted in antagonizing the "people" against an imaginary foe.

scite: Colombia 2016. Religions, v. 9, 2018.

131 The Catatumbo clause sustains that "No content of the Final Agreement will be understood and interpreted as the denial, restriction or impairment of the rights of people regardless of their sex, age, religious beliefs, opinions, ethnic identity, for their membership in the Lgbti population or for any other reason; nor the right to the free development of personality and the right to freedom of conscience". FINAL PEACE AGREEMENT. Final agreement to end the armed conflict and build a stable and lasting peace. 2016. Available at: http://www.altocomisionadoparalapaz.gov.co/Prensa/Documentos $\% 20$ compartidos/Colombian-Peace-Agreement-English-Translation.pdf.

132 VÉLEZ, Juanita. Cristianos y LGBTI: ambos sienten que ganaron con el acuerdo. La Silla Vacia, nov. 2016. Available online: http://lasillavacia.com/historia/cristianos-y-Lgbti-ambos-sientenque-ganaron-con-el-acuerdo-58838.

133 BELTRÁN, William Mauricio; CREELY, Sian. Pentecostals, gender ideology and the peace plebiscite: Colombia 2016. Religions, v. 9, 2018.
This "us vs them" narrative has gained support among Evangelical neo-Pentecostal followers. As they usually identify with a more conservative agenda, they have use right-wing populist platforms to spread their moral values and consolidate a position within politics. Conversely, populists have embraced Evangelical rhetoric to reach an incredible number of faithful. Thus, populism appears as a two-way bridge between the conservative Evangelical faithful and right-wing politicians.

In Latin America, LGBTI rights have recently been brought to the heart of the political debate, and both right-ring populists and neo-Pentecostals took the opportunity to defend the so-called respectable citizen as an important part of their agenda. They gathered in an anti-LGBTI force, which talks to a single audience, thirsting for a political representation able to stop LGBTI's empowerment.

In Colombia, the peace negotiations have generated considerable attention among the international community. It has also gathered a substantial level of domestic political support. This attention and support helped create a powerful narrative to make LGBTI groups stand out in the general population of victims. However, the spotlight has also contributed to the backlash against these groups. Therefore, the referendum became a platform for advancing and repudiating LGBTI rights, where both the supporters and opponents of the agreement's gender-based approach saw this political process as a chance to further their own agenda.

Although some LGBTI achievements were regrettably "lost in translation" at the Final Agreement, the document is still the most gender- and LGBTI-sensitive peace deal to date. Despite the largely unexpected referendum's outcome, the sharp opposition of right-wing populists and the neo-Pentecostal leaders in the Colombian peace process does not come as a surprise to anyone who considers a regional overview and historical background of the backlash against the LGBTI community.

Latin America is indeed like a "sandwich", stuck between right-wing populism and neo-Pentecostal churches. In order to create an enemy, these actors help build the mirage of a looming LGBTI menace, blaming the LGBTI community for the decline of the so-called traditional family. Anyone who opposes this idea is out of touch with "ordinary" people, obsessed with "marginal issues such as LGBTI rights". They are naive drea- 
mers in their own attachment to such vague notions as "human rights".

\section{References}

ALTHOFF, Andrea. Right-wing populism and evangelicalism in Guatemala: the presidency of Jimmy Morales. International Journal of Latin American Religions, v. 3, p. 294-324, 2019.

ANDERSON, Jon Lee. How Colombia's voters rejected peace. The New Yorker, oct. 2016. Available at: https:// www.newyorker.com/news/daily-comment/how-colombias-voters-rejected-peace.

BASSET, Yann. Claves del rechazo del plebiscito para la paz en Colombia. Estudios Políticos, Medellín, v. 52, p. 241-265, 2017.

BATTAGLINO, Jorge; LODOLA, Germán. Negotiations and possible spoilers in the Colombian peace process. Norwigian Peace Building Resource Center, Expert Analysis, 2013.

BAVA, Silvio Caccia; ROMANO, Jorge. Vamos falar de populismo. Le Monde Diplomatique Brasil, ed. 120, jul. 2017. Available at: https://diplomatique.org.br/vamosfalar-de-populismo-2/.

BBC NEWS. Colombia Farc conflict: Uribe says peace deal was 'weak' after Santos meeting. BBC News, oct. 2016. Available at: https://www.bbc.com/news/worldlatin-america-37558825.

BELLAL, Annyssa. The war report: armed conflicts in 2016. Geneva Academy of International Humanitarian Law and Human Rights, 2017. Available at: https://ssrn.com/abstract $=30858$.

BELLOLIO, Cristóbal. La cuarta ola de populismo latinoamericano. Revista Capital, 2018. Available at: https:/ / www.capital.cl/la-cuarta-ola-de-populismo-latinoamericano/.

BELTRÁN, William Mauricio; CREELY, Sian. Pentecostals, gender ideology and the peace plebiscite: Colombia 2016. Religions, v. 9, 2018.

BOAS, Taylor. Serving God and man: evangelical christianity and electoral politics in Latin America. Annual meeting of the American Political Science Association, Chicago, aug. 29/sep. 1, 2013.

CADENA SER. Juan Manuel Santos: América Latina está como un sándwich, entre el populismo de izquierdas y de derechas. Cadena Ser, mar. 2019. Available at: https://cadenaser.com/programa/2019/03/27/hoy_ por_hoy/1553671611_425302.html.

BBC NEWS. Conservative Alejandro Giammattei wins Guatemalan presidency. BBC News, aug. 2019. Available at: https://www.bbc.com/news/world-latin-america-49278325.

CÉSPEDES-BÁEZ, Lina M. Gender panic and the failure of a peace agreement. AJIL Unbound, v. 110, p. 183-187, 2016.

BBC NEWS. Chile election: conservative Piñera elected president. BBC News, dec. 2019. Available at: https:// www.bbc.com/news/world-latin-america-42388019.

BBC NEWS. Colombia Farc conflict: Uribe says peace deal was 'weak' after Santos meeting. BBC News, oct. 2016. Available at: https://www.bbc.com/news/worldlatin-america-37558825.

CORRALES, Javier; PECHENY, Mario. Introduction: the comparative politics of sexuality in Latin America. In: CORRALES, Javier; PECHENY, Mario (org.). The politics of sexuality in Latin America. Pittsburgh: University of Pittsburgh Press, 2010. p. 1-30.

CORRALES, Javier. A perfect marriage: evangelicals and conservatives in Latin America. The New York Times, jan. 2018. Available at: https://www.nytimes. com/2018/01/17/opinion/evangelicals-politics-latinamerica.html.

CORRALES, Javier. The expansion of LGBT rights in Latin America and the backlash. In: BOSIA, Michael; MCEVOY, M. Sandra; RAHMAN, Momin (org.). The Oxford Handbook of Global LGBT and Sexual Diversity Politics, 2019.

EL ESPECTADOR. Para Marco Fidel Ramírez, Colombia será "ateo-marxista y homosexual" tras firma de paz. El Espectador, sep. 2016. Available at: http:// www.elespectador.com/noticias/bogota/marco-fidelramirez-colombia-sera- -ateo-marxista-y-homos-articulo-656908.

EL ESPECTADOR. El acuerdo con las Farc no promueve la ideología de género": Santos. El Espectador, oct. 2016. Available at: https://www.elespectador.com/ noticias/politica/el-acuerdo-farc-no-promueve-ideologia-de-genero-santos-articulo-660110.

ESPITIA, Monica. LGBT in Colombia: a war within. 
CUNY Academic Works, 2016. Available at: https://academicworks.cuny.edu/gj_etds/150.

FINAL PEACE AGREEMENT. Final agreement to end the armed conflict and build a stable and lasting peace. 2016. Available at: http://www.altocomisionadoparalapaz. gov.co/Prensa/Documentos $\% 20$ compartidos/Colombian-Peace-Agreement-English-Translation.pdf.

GANDESHA, Samir. Understanding right and left populism. In: MORELOCK, Jeremiah (org.). Critical theory and authoritarian populism. London: University of Westminster Press, 2018. p. 49-70.

GIROUX, Henry A. Crescimento do populismo de direita. Le Monde Diplomatique Brasil, ed. 151, jan. 2020. Available at: https://diplomatique.org.br/crescimentodo-populismo-de-direita/.

GOLDSTEIN, Joshua S. War and gender: how gender shapes the war system and vice versa. Cambridge: Cambridge University Press, 2001.

GRATIUS, Susanne. La "tercera ola populista" de América Latina. Working paper to the Fundación para las Relaciones Internacionales y el Diálogo Exterior (FRIDE). oct. 2007. Available at: https://s3.amazonaws.com/academia.edu.documents/42469813/La_tercera_ola_populista_de_Amrica_Latin20160209-25129-13dj5fo.pdf.

GRATTAN, Steven. The emerging challenges and opportunities for the LGBT+ population in post-accord Colombia. Thesis for: MA Human Rights and Global Ethics. Universidad del Rosario, 2018.

GUADALUPE, José Luis Pérez. Evangelicals and political power in Latin America. Lima: Konrad-Adenauer-Stiftung \& Institute of Social Christian Studies of Peru (IESC), 2019.

HERNANDEZ, Alejandro Espí. La dimensión emocional de los movimientos políticos populistas del XXI en América Latina y Europa. Miguel Hernández Communication Journal, v. 1, n. 10, p. 101-121, 2017.

HUMAN RIGHTS COUNCIL. Report of the Special Rapporteur on Extrajudicial, Summary or Arbitrary Executions on a Gender-Sensitive Approach to Arbitrary Killings. UN Doc. A/HRC/ 35/23, jun. 2017, paras 47-48.

INTER-AMERICAN COMMISSION OF HUMAN RIGHTS. Violence against LGBTI persons in the Americas. Washington, DC: Inter-American Commission on $\mathrm{Hu}-$ man Rights, 2015, para. 279, 345.
LAMBERT, Renaud. O impasse da direita da América Latina. Le Monde Diplomatique Brasil, ed. 152, fev. 2020. Available at: https://diplomatique.org.br/o-impasseda-direita-na-america-latina/.

MAINWARING, Scott; MENEGUELLO, Rachel; POWER, Timothy J. Conservative parties, democracy, and economic reform in contemporary Brazil. In: MIDDLEBROOK, Kevin J. Conservative parties, the right, and democracy in Latin America. Baltimore: The Johns Hopkins University Press, 2000. p. 164-222.

MALDONADO, Andrés Ucrós. What is the Colombian peace process teaching the World?. New England Journal of Public Policy, v. 29, n. 1, 2017.

MARGALIT, Alon. Still a blind spot: the protection of LGBT persons during armed conflict and other situations of violence. International Review of the Red Cross, v. 100, n. 907-909, p. 237-265, 2018.

MARIANO, Ricardo; GERARDI, Dirceu André. Eleições presidenciais na América Latina em 2018 e ativismo político de evangélicos conservadores. Revista da Universidade de São Paulo, n. 120, p. 61-76, 2019.

MUDDE, Cas. The populist Zeitgeist. Government and Opposition, v. 39, n. 4, p. 541-563, 2004.

MUDDE, Cas; KALTWASSER, Cristóbal Rovira. Populism: a very short introduction. Oxford: Oxford University Press, 2017.

MULLER, Jan Werner. Populism and the people. London Review of Books, may 2019. Available at: https:// www.lrb.co.uk/the-paper/v41/n10/jan-werner-mueller/populism-and-the-people.

MYRTTINEN, Henri; DAIGLE, Megan. When merely existing is a risk: sexual and gender minorities in conflict, displacement and peacebuilding. London: International Alert, 2017.

PAYNE, Stanley G. A history of Spain and Portugal. The Library of Iberian Resources Online. Available at: https://libro.uca.edu/payne1/spainport1.htm.

PENYAK, Lee M.; PETRY, Walt J. Religion in Latin America: a documentary history. New York: Orbis Books, 2006.

PEW RESEARCH CENTER. Religion in Latin America: widespread change in a historically catholic region. Pew Research Center, nov. 2014.

PRADO, Maria Ligia; PELLEGRINO, Gabriela. Hi- 
stória da América Latina. São Paulo: Contexto, 2014.

PRETEL, Enrique Andres. Christian singer faces leftist author in Costa Rica presidential runoff. Reuters, feb. 2018. Available at: https:/ /www.reuters.com/article/uscostarica- election/christian-singer-faces-leftist-authorin-costa-rica-presidential-runoff-idUSKBN1FP0QE.

RONDÓN, Manuel Alejandro Rodríguez. La ideología de género como exceso: pánico moral y decisión ética en la política colombiana. Sexualidad, Salud y Sociedad, Rio de Janeiro, n. 27, p. 128-148, 2017.

SABOGAL, Julián. Evangélicos se consolidan cada vez más como una fuerza política en Suramérica. RCN Radio, 2018. Available at: https://www.rcnradio.com/ internacional/evangelicos-se-consolidan-cada-vez-mascomo-una-fuerza-politica-en-suramerica.

SEMANA. Las ocho peticiones de los pastores del No. Semana, oct. 2016. Available at: http://www.semana. $\mathrm{com} /$ nacion/articulo/las-ocho-peticiones-de-los--pastores-que-votaron-no-en-el-plebiscito/499219.

SEMANA. Cristianos: ¿el poder decisorio en la política? Semana, oct. 2016. Available at: http://www.semana. $\mathrm{com} /$ nacion/articulo/religion-inclina-la-balanza-politica-en-colombia/502530.

SEMÁN, Pablo. ¿Quiénes son? ¿Por qué crecen? ¿En qué creen? Pentecostalismo y política en América Latina. Revista Brasileira de Ciências Sociais, v. 34, n. 99, p. 26-45, 2019.

SILVA, Hélerson. Os novos atores "evangélicos" e a conquista do espaço público na América Latina. Reflexão, v. 43, n. 2, p. 243-263, 2018.

SMILDE, David. Los evangélicos y la polarización. Revista Venezolana de Economía y Ciencias Sociales, v. 10, n. 2, p. 163-179, 2004.

TATE, Winifred. A dark day in Colombia. Nacla, oct. 2016. Available at: https://nacla.org/ news/2016/10/04/dark-day-colombia-0.

THE GUARDIAN. Honduran president makes contentious bid for second term. The Guardian, nov. 2017. Available at: https://www.theguardian.com/ world/2017/nov/24/honduras-president-hernandezcontentious-bid-second-term-elections.

THYLIN, Theresia. Violence, toleration, or inclusion? Exploring variation in the experiences of LGBT combatants in Colombia. Sexualities, v. 23, p. 1-20, 2019.
UNITED NATIONS GENERAL ASSEMBLY. Resolution. 71/198, 19 December 2016, para. 6.

URUEÑA, Rene. Reclaiming the keys to the kingdom (of the World): evangelicals and human rights in Latin America. Netherlands Yearbook of International Law. Populism and International Law, p. 175-208, 2018.

VÉLEZ, Juanita. El Sí pierde un aliado por "la familia". La Silla Vacia. aug. 2016. Available at: http://lasillavacia.com/historia/el-si-pierde-un-aliado-por-lafamilia-57572.

VÉLEZ, Juanita. Cristianos y LGBTI: ambos sienten que ganaron con el acuerdo. La Silla Vacia, nov. 2016. Available online: http://lasillavacia.com/historia/ cristianos-y-Lgbti-ambos-sienten-que-ganaron-con-elacuerdo-58838. 
Para publicar na Revista de Direito Internacional, acesse o endereço eletrônico www.rdi.uniceub.br ou www.brazilianjournal.org.

Observe as normas de publicação, para facilitar e agilizar o trabalho de edição. 